\title{
Simultaneous Decision Making of Child Schooling and Child Labour in Pakistani Urban Households
}

\author{
Karamat Ali and Rana Ejaz Ali Khan ${ }^{*}$
}

\section{Introduction}

In recent years, there has been a rapidly expanding literature on child labour that provides empirical evidence on its nature and determinants. The previous literature on Pakistani child labour includes Khan (1982), Hussain (1985), Ahmed (1991), Khan and Ali (1991) and Weiner and Noman (1995), and recently Addision, et. al. (1997), Burki and Fasih (1998), Ray (2000a), Ray (2000b), Ray (2001) and Ali and Khan (2003). Some studies (see for instance Khan 1982; Ahmed 1991) discuss mainly the qualitative features of child labour. The recent literature has focused attention on the quantitative aspect, taking advantage of the increasing availability of good quality data on child labour. Within the empirical literature on child labour, there has been a shift in emphasis from more quantification to an econometric analysis of its determinants. As child labour is seen to result from the same variables influencing child schooling but in inverse, so school enrolment is strongly correlated with child labour. Child labour commitments are major reasons for children's non-participation in school. So the literature has moved to incorporate child schooling and child labour and thus analyses schooling and child labour jointly (see for instance, Degraff et. al. 1993; Mahmood et. al. 1994). The present study is one of this category.

Notwithstanding almost universal agreement that child labour is undesirable, there is wide disagreement on how to tackle this problem. The formulation of policies that are effective in curbing child labour require an analysis of its key determinants, namely identification of variables that have a significant effect on child labour. Ray (2000a) shows that child labour takes different forms in different regions, and the nature of child labour, its key determinants and consequently, the strategies to reduce it vary within regions.

\footnotetext{
* Karamat Ali is Dean, Faculty of Commerce, Law and Business Administration, BZU, Multan and Rana Ejaz Ali Khan is lecturer in Economics, Government Faridia College, Pakpattan and currently Ph.D. scholar at BZU, Multan.
} 
According to Federal Bureau of Statistics (1996) among the 40 million children aged 5-14 years, 3.3 million, i.e. 8.3 percent are economically active in Pakistan. Of them 2.4 million $(73$ percent of child labour force) child labourers are boys and 0.9 million (27 percent of child labour force) are girls. The urban child population is 11.7 million, that is 28 percent of the total child population. Urban child labour is one-eighth of rural child labour.

A number of studies (Ahmed 1991; Weiner and Noman 1995; Addison et. al. 1997) indicate that poverty is one of the major causes of child labour. In the urban areas of Pakistan 22.4 percent of the population lives below the poverty line as compared to 36.3 percent in rural areas (ADB 2002:12). The average income of the households in urban areas is higher as compared to their rural counterparts. The income distribution in urban areas is more unequal than rural areas (ADB 2002:10). The socio-physical infrastructure is better in urban areas. The largest urban center of Pakistan, Karachi is growing at the rate of 3.8 percent annually with the present human population of 11.8 million. About 45 percent of the population of the city lives in Katchi Abadis and squatter settlements and 35 percent lives below the poverty line. An urban child is more likely to be in school than its rural counterpart (Durrant 1998:37; Maitra and Ray 2000:15). Gross Primary Enrolment Rate is 97 percent in urban areas and 63 percent in rural areas of Pakistan. For boys it is 95 and 75 percent and for girls 92 and 50 percent for urban and rural areas respectively. This means that not only the enrolment rate is higher in urban areas but also the gender disparity in urban areas is less as compared to rural areas (ADB 2002:21). It seems that urban households in Pakistan have specific characteristics, which determine child schooling and child labour decisions. This fact leads to the need for the present study, i.e. to analyse child schooling and child labour decision of urban households. The point of departure of the present study from its predecessors lies in the use of primary data collected by researchers. The previous studies (see, Burki and Fasih 1998) used the data collected by the Federal Bureau of Statistics (FBS 1996), which was collected by a cluster study where the cluster has a concentration of child labour. Although we had used the cluster sample technique, the sample was selected so that it consisted of all the households of all income groups regardless of concentration of child labour.

\section{Objectives}

The principal objective of the study is to contribute to the analytical and empirical basis for answering the policy question of whether and to what extent changes in the education of the child, household income, education 
level of parents, unemployment level of parents and the demographic factor could effectively reduce child labour. Based on the results, the study briefly describes the possible policy strategies for influencing the changes in these variables.

The precise objectives of the study are to analyse the supply side determinants of child labour in urban areas, i.e. to determine the relation between the decision of the parents (to send their children to school only, school and work, work only or no school no work) and four categories of socio-economic variables as: Child Characteristics (Birth order of the child, Gender of the child, Age of the child, Education of the child), Head of the Household Characteristics (Gender of the head of the household, Age of the head of the household, Education of the head of the household, Employment status of the head of the household, Income of the head of the household), Parent's Characteristics (Education of the father, Employment status of father, Income of the father, Education of the mother, Employment status of mother, Income of the mother), Household Characteristics (Ownership of the assets, per capita expenditure of the household, Family size, Composition of the household, i.e. number of children in the age group of less than 5 years and those in 5-15 years.

\section{Methodology}

Definitions and Concepts: The definition of child labour to be used in the study is that the participation of school age children (in the age group of 5-15) in the labour force i.e. work for wage or in household enterprises to earn a living for themselves or to support household income. A child is defined as a person of 5-15 years old. The 15 years age coincides with the end of the school age. Likewise cutoff age between infancy and childhood is the age of 5 .

Household: Household is a single person living alone or a group of persons who normally live and eat together under common cooking arrangement and have no other usual place of residence elsewhere.

Income of Household: Income of the household, which is one of the economic determinants of child labour and child schooling, is defined as non-child household income. This reflects the assumption that decisions on child labour are taken after adult and other non-child earnings are determined. Such a view, also, underlies the 'Luxury Axiom' of Basu and Van (1998), namely, that a family will send the child to the labour market only if the family's income from non child labour sources drops very low. 
Household Members: Include all such persons present or temporarily absent whose usual place of residence falls in the selected household at the time of enumeration.

Head of Household: Head of household means the representative of the family who has power to supervise its members and is the main bread earner of the household. Usually one of the parents is the head of the household, but one of the grand parents may act as the head of the household in a combined family system or in the case of missing parents. If parents, grandparents, all are not members of the household then the eldest person of the household acts as head of the household and makes the decisions of the household. Some times parents or grand parents are the members of the household but are too old, then the eldest person after them takes the responsibilities of the head of the household.

Urban areas: Urban area is defined as the area within the boundaries of municipal committee and the rural areas are the areas outside the boundaries of municipal and town committees. If the household lives in an urban area while some children or persons are working in rural areas, the household is considered as an urban household.

Development of Instrument: A questionnaire and comprehensive interview schedule was developed. The interview schedule was structured so that the information revealed can easily be analysed by a computer.

Universe: Universe of the survey comprised all the urban households of all income groups in the country.

Sample Design: Cluster sample technique was adopted. Sample of the population, i.e. district Pakpattan was selected intentionally. There were a large number of colonies and mohallas in the district but the study area was confined to some selected colonies/mohallas. These clusters represented the average conditions of the area so these were selected intentionally. The households in the selected area represented all income groups and all walks of life.

Source of Data: Field surveys were the main source of data that were conducted in six clusters for the study and the data was collected by a household survey. Moreover, personal observations supported the subject.

Area of Survey: To keep the study within manageable limits, a sample study was proposed. The sample observations consisted of two thousand urban households from district Pakpattan. 
Mode of Survey: Interviewing the head of the household was the mode of collecting data. The information was collected through questionnaires which consisted of dichotomous, multiple choice and open-ended questions. The interview was conducted at the homes of the interviewee and the researcher made door-to-door contact with the interviewee.

Model: There are several ways to econometrically model the decision of child schooling and child labour. Most of the work is based on the contribution of Rosenzweig and Evenson (1997) that has the setting of standard constrained utility maximisation model of the household. Many researchers (see for instance Lavy 1985; Rivera-Batiz 1985; Sharif 1994) followed the same criterion. For the analysis of the determinants of schooling and child labour a reduced-form model is developed and adopted by many researchers (see Grootaert 1999a; Cartwright 1999; Cartwright and Patrinos 1999; Ray 2000a; and Ray 2000b). The present study has followed the same studies.

As far as the decision making process within the household is concerned, there is no direct evidence in the literature on household's decision-making process, i.e. whether the household makes a simultaneous decision or hierarchical decision. The sequential model approach has advantages over the simultaneous approach (see Grootaert 1999b). In order to disentangle the conflicting determinants of schooling and child labour and to assess the relative importance of each of the factors influencing schooling and child labour decisions, the household decision-making is empirically estimated in the context of a sequential probit model. The households are assumed to use a sequential process. So in the study, the decision of child schooling and child labour is analysed as a sequential decision making process. The sequential choices making the welfare of the child were assumed as: (i) schooling (ii) schooling and work (iii) work only (iv) neither schooling nor work. This leads to the following four choices, and choice probabilities, to be estimated for each child:

$\mathrm{P}_{1}=$ Probability to go to school and not to work.

$\mathrm{P}_{2}=$ Probability to go to school and to work.

$\mathrm{P}_{3}=$ Probability not to go to school but to work.

$\mathrm{P}_{4}=$ Probability neither to go to school nor to work.

In the sequential probit model the probabilities for the four choices are determined as followed:

$$
\mathrm{P}_{1}=\mathrm{f}\left(\mathrm{b}_{1 \mathrm{X}}\right)
$$




$$
\begin{aligned}
& P_{2}=\left(1-f\left(b_{1} X\right)\right) f\left(b_{2} X\right) \\
& P_{3}=\left(1-f\left(b_{1} X\right)\right)\left(1-f\left(b_{2} X\right)\right) f\left(b_{3} X\right) \\
& P_{4}=\left(1-f\left(b_{1} X\right)\right)\left(1-f\left(b_{2} X\right)\right)\left(1-f\left(b_{3} X\right)\right) f\left(b_{4} X\right)
\end{aligned}
$$

Where $f$ represents the standard normal distribution function, and $b_{1}$, $b_{2}$, and $b_{3}$ are vectors of the model parameters. The vector $X$ contains the explanatory variables. Parameters $b_{1}$ are estimated over the entire sample. Parameters $b_{2}$ are estimated over the sample of children excluding those who go to school only. Parameters $b_{3}$ estimated over the sample of children excluding those who go to school only, and who go to school and work simultaneously.

The Independent Variables: Three groups of explanatory variables have been selected as determinants of child schooling and child labour, i.e. child characteristics, head of household characteristics, parent characteristics and household characteristics. The variables have been selected on the basis of related previous economic literature (See, Burki and Fasih 1998; Cartwright 1999; Cartwright and Patrinos 1999; Ray 1999; Grootaert 1999; Ray 2000a; Ray 2000b; Maitra and Ray 2000; Sawada and Lokshin 2000; Ray 2001; Ali and Khan 2003).

Child characteristics: The present study model includes birth order, the gender of the child, age of child in completed years, squared age of the child, and number of years of formal education as explanatory variables.

Head of Household Characteristics: Gender of the head of household, age of the head of household, squared age of the head of the household, education level of head of household, employment situation of the head of household and income of the head of household.

Parent's Characteristics: The model includes the parent's characteristics (separately of father and mother) as explanatory variables. These are number of years of education, employment status of parents and income of parents.

Household Characteristics: The variables included are the household's ownership of income-generating assets (such as a household business, house, shop, land, or farm equipment, etc.), per capita expenditure of the household, family size, i.e. number of family members, the number of children less than 5 years and 5-15 years. Table 1.

The variables used in the sequential probit model are represented in 
Table-1:

\begin{tabular}{|c|c|}
\hline VARIABLES & DEFINITION \\
\hline \multicolumn{2}{|l|}{ Dependent Variables } \\
\hline $\mathrm{P}_{1}$ (Child goes to school only) & $\begin{array}{l}1 \text { if child goes to school and not } \\
\text { to work, } 0 \text { otherwise }\end{array}$ \\
\hline $\begin{array}{l}\mathrm{P}_{2} \text { (Child goes to school as well as } \\
\text { to work) }\end{array}$ & $\begin{array}{l}1 \text { if child goes to school and to } \\
\text { work, } 0 \text { otherwise }\end{array}$ \\
\hline $\begin{array}{l}\mathrm{P}_{3} \text { (Child does not go to school } \\
\text { but to Work) }\end{array}$ & $\begin{array}{l}\text { 1if child does not go to school but } \\
\text { to work, } 0 \text { otherwise }\end{array}$ \\
\hline $\begin{array}{l}\mathrm{P}_{4} \text { (Child neither goes to school } \\
\text { nor work) }\end{array}$ & $\begin{array}{l}1 \text { if child neither go to school nor } \\
\text { to work, } 0 \text { otherwise }\end{array}$ \\
\hline \multicolumn{2}{|l|}{ Independent Variables } \\
\hline \multicolumn{2}{|c|}{ Child Characteristics } \\
\hline Bord (Birth order of child) & $\begin{array}{l}\text { Birth order of child in his/her } \\
\text { brothers and sisters }\end{array}$ \\
\hline Cgen (Child's gender) & 1 if child is male, 0 otherwise \\
\hline Cage (Child's age) & Child's age in completed years \\
\hline Cagesq (Child's age squared) & Child's age squared \\
\hline Cedu (Child's education) & $\begin{array}{l}\text { Child's education in completed } \\
\text { years of education }\end{array}$ \\
\hline $\begin{array}{l}\text { Hgen (Head of household's } \\
\text { gender) }\end{array}$ & $\begin{array}{l}1 \text { if head of the household is male, } \\
0 \text { otherwise }\end{array}$ \\
\hline Hage (Head of household's age) & $\begin{array}{l}\text { Head of household's age in } \\
\text { completed years }\end{array}$ \\
\hline $\begin{array}{l}\text { Hagesq (Head of household's age } \\
\text { squared) }\end{array}$ & $\begin{array}{l}\text { Head of household's age squared } \\
\text { in completed years }\end{array}$ \\
\hline $\begin{array}{l}\text { Hedu (Head of the household's } \\
\text { education) }\end{array}$ & $\begin{array}{l}\text { Head of the household's completed } \\
\text { years of education }\end{array}$ \\
\hline $\begin{array}{l}\text { Hemp (Head of household's } \\
\text { employment) }\end{array}$ & $\begin{array}{l}1 \text { if Head of household's employed, } \\
0 \text { otherwise }\end{array}$ \\
\hline Hy (Head of household's income) & $\begin{array}{l}\text { Head of household's income per } \\
\text { month }\end{array}$ \\
\hline \multicolumn{2}{|c|}{ Parent's Characteristics } \\
\hline Fedu (Father's education) & $\begin{array}{l}\text { Father's education in completed } \\
\text { years of education }\end{array}$ \\
\hline Femp (Father' employment) & 1 if father is employed, 0 otherwise \\
\hline Fy (Father's income) & Father's income per month \\
\hline Medu (Mother's education) & $\begin{array}{l}\text { Mother's completed years of } \\
\text { education }\end{array}$ \\
\hline Memp (Mother's employment) & 1 if mother is employed, 0 otherwise \\
\hline My (Mother's income) & Mother's income per month \\
\hline
\end{tabular}




\section{Household Characteristics}

\begin{tabular}{|c|c|}
\hline $\begin{array}{l}\text { Asst (Household's ownership of } \\
\text { assets) }\end{array}$ & $\begin{array}{l}1 \text { if the household has ownership } \\
\text { of assets, } 0 \text { otherwise }\end{array}$ \\
\hline $\begin{array}{l}\text { Pcexp (Per Capita Expenditure of } \\
\text { Household) }\end{array}$ & $\begin{array}{l}\text { Household's per capita expenditure } \\
\text { in Rupees per month }\end{array}$ \\
\hline Fmsiz (Household family size) & Number of household members \\
\hline Child 015 & $\begin{array}{l}\text { Number of children ages } 15 \text { or less } \\
\text { than } 15 \text { years in the household }\end{array}$ \\
\hline Child 04 & $\begin{array}{l}\text { Number of children ages } 4 \text { or less } \\
\text { than } 4 \text { years in the household }\end{array}$ \\
\hline Child 515 & $\begin{array}{l}\text { Number of children ages } 5-15 \\
\text { years in the household }\end{array}$ \\
\hline
\end{tabular}

\section{Results and Discussion}

The sequential probit results are presented in Table 2 for the children aged 5-15 in the urban areas of Pakistan. The table reports the probability derivatives of the parameters estimates, computed at the means of the explanatory variables. These derivatives show the percentage point change in probability for a one unit increase at the mean of a given explanatory variable holding all other variables constant at the mean. In the parentheses the t-statistics are shown. The majority of the results are consistent with the theoretical implications of child labour. 
Table-2: Sequential Probit Results for Urban Households

\begin{tabular}{|c|c|c|c|c|}
\hline Variables & $\begin{array}{l}\text { First Stage } \\
\mathrm{P}_{1}=\text { Probability } \\
\text { that the Child } \\
\text { Goes to School } \\
\text { Only }\end{array}$ & $\begin{array}{l}\text { Second Stage } \\
\mathrm{P}_{2}=\text { Probability } \\
\text { that the Child } \\
\text { Goes to School } \\
\text { as well as Work }\end{array}$ & $\begin{array}{l}\text { Third Stage } \\
\mathrm{P}_{3}=\text { Probability } \\
\text { that the Child } \\
\text { does not go to } \\
\text { School but Work }\end{array}$ & $\begin{array}{l}\text { Fourth Stage } \\
\mathrm{P}_{4}=\text { Probability } \\
\text { that the Child } \\
\text { neither go to } \\
\text { School nor Work }\end{array}$ \\
\hline Constant & $\begin{array}{l}-1.9140 \\
(-1.5307)\end{array}$ & $\begin{array}{l}-0.5248 \\
(-2.7117) \\
\end{array}$ & $\begin{array}{l}-1.8993 \\
(-1.7065) \\
\end{array}$ & $\begin{array}{l}1.9447 \\
(2.2766) \\
\end{array}$ \\
\hline \multicolumn{5}{|c|}{ Child Characteristics } \\
\hline Bord & $\begin{array}{l}-0.0047 \\
(-1.3302)^{* * *}\end{array}$ & $\begin{array}{l}-0.0084 \\
(-1.2863)^{* *}\end{array}$ & $\begin{array}{l}-0.0115 \\
(-1.2656)^{* * *}\end{array}$ & $\begin{array}{l}0.0186 \\
(1.4903)^{*}\end{array}$ \\
\hline Cgen & $\begin{array}{l}0.1081 \\
(1.8908)^{*}\end{array}$ & - & $\begin{array}{l}-0.0428 \\
(-1.6251)^{* * *}\end{array}$ & $\begin{array}{l}-0.0122 \\
(1.2869)^{* *}\end{array}$ \\
\hline Cage & $\begin{array}{l}0.1742 \\
(2.1273)^{*}\end{array}$ & $\begin{array}{l}1.0852 \\
(1.3768)^{* * *}\end{array}$ & $\begin{array}{l}0.0709 \\
(1.9148)^{*}\end{array}$ & $\begin{array}{l}-0.0822 \\
(-1.2991)^{* * *}\end{array}$ \\
\hline Cagesq & $\begin{array}{l}-0.0123 \\
(-2.5559)^{*}\end{array}$ & $\begin{array}{l}-0.0001 \\
(-1.2966)^{* *}\end{array}$ & $\begin{array}{l}-0.0026 \\
(1.6934)^{*}\end{array}$ & $\begin{array}{l}0.0049 \\
(1.4620)^{* * *}\end{array}$ \\
\hline Cedu & $\begin{array}{l}0.0357 \\
(1.8849)^{*} \\
\end{array}$ & $\begin{array}{l}0.0111 \\
(4.2011)^{*}\end{array}$ & $\begin{array}{l}-0.0258 \\
(-1.5641)^{* *} \\
\end{array}$ & $\begin{array}{l}-0.0795 \\
(-3.0463)^{* *}\end{array}$ \\
\hline \multicolumn{5}{|c|}{ Head of Household Characteristics } \\
\hline Hgen & $\begin{array}{l}0.0010 \\
(1.3910)^{* * *}\end{array}$ & - & $\begin{array}{l}0.0000 \\
(0)\end{array}$ & $\begin{array}{l}0.0000 \\
(0)\end{array}$ \\
\hline Hage & $\begin{array}{l}0.0654 \\
(1.3110)^{* *}\end{array}$ & $\begin{array}{l}0.0185 \\
(0.2662)\end{array}$ & $\begin{array}{l}0.0802 \\
(1.5973)^{* * *}\end{array}$ & $\begin{array}{l}-0.0968 \\
(-2.5054)^{*}\end{array}$ \\
\hline Hagesq & $\begin{array}{l}-0.0007 \\
(-1.7433)^{*}\end{array}$ & $\begin{array}{l}-0.0001 \\
(-0.1287)\end{array}$ & $\begin{array}{l}-0.0008 \\
(-1.5221)^{* *}\end{array}$ & $\begin{array}{l}0.0011 \\
(2.5726)^{*}\end{array}$ \\
\hline Hedu & $\begin{array}{l}-0.1491 \\
(-1.3095)^{* *}\end{array}$ & $\begin{array}{l}0.0002 \\
(-0.0100)\end{array}$ & $\begin{array}{l}-0.9830 \\
(-1.7205)^{* * *}\end{array}$ & $\begin{array}{l}-0.2299 \\
(-2.2618)^{*}\end{array}$ \\
\hline Hemp & $\begin{array}{l}-0.0903 \\
(-1.6094)^{* * *}\end{array}$ & - & $\begin{array}{l}-0.1703 \\
(-1.5086)^{* * *}\end{array}$ & $\begin{array}{l}0.2576 \\
(1.8622)^{*}\end{array}$ \\
\hline Hy & $\begin{array}{l}0.0001 \\
(1.1348)^{* * *}\end{array}$ & $\begin{array}{l}-0.0000 \\
(-0.9395) \\
\end{array}$ & $\begin{array}{l}-0.0063 \\
(-1.1484)^{* * *} \\
\end{array}$ & $\begin{array}{l}0.0000 \\
(0.9341) \\
\end{array}$ \\
\hline \multicolumn{5}{|c|}{ Parent's Characteristics } \\
\hline Fedu & $\begin{array}{l}0.2135 \\
(1.4434)^{* * *}\end{array}$ & $\begin{array}{l}-0.0043 \\
(-0.1581\end{array}$ & $\begin{array}{l}-0.9727 \\
(1.7131)^{*}\end{array}$ & $\begin{array}{l}0.2061 \\
(1.6348)^{*}\end{array}$ \\
\hline Femp & $\begin{array}{l}0.0000 \\
(0)\end{array}$ & - & $\begin{array}{l}0.0000 \\
(0)\end{array}$ & $\begin{array}{l}0.0000 \\
(0)\end{array}$ \\
\hline Fy & $\begin{array}{l}0.0000 \\
(0)\end{array}$ & $\begin{array}{l}0.0000 \\
(0.0853)\end{array}$ & $\begin{array}{l}0.0000 \\
(0)\end{array}$ & $\begin{array}{l}0.0000 \\
(0)\end{array}$ \\
\hline Medu & $\begin{array}{l}0.2366 \\
(1.6535)^{*}\end{array}$ & $\begin{array}{l}-0.0046 \\
(-1.8397)^{* *}\end{array}$ & $\begin{array}{l}-0.0347 \\
(-1.2836)^{* *}\end{array}$ & - \\
\hline Memp & $\begin{array}{l}0.1674 \\
(-1.2991)^{* * *}\end{array}$ & - & $\begin{array}{l}0.0381 \\
(1.3180)^{* * *}\end{array}$ & $\begin{array}{l}-0.1844 \\
(-1.3533)^{* * *}\end{array}$ \\
\hline My & $\begin{array}{l}0.0003 \\
(1.5902)^{* * *}\end{array}$ & $\begin{array}{l}3.1435 \\
(1.2758)^{* * *}\end{array}$ & $\begin{array}{l}0.0000 \\
(1.3937)^{* * *}\end{array}$ & $\begin{array}{l}-0.0001 \\
(-1.4330)^{* * *}\end{array}$ \\
\hline \multicolumn{5}{|c|}{ Household Characteristics } \\
\hline Asst & $\begin{array}{l}0.0805 \\
(1.8925)^{*}\end{array}$ & $\begin{array}{l}-0.0163 \\
(-1.1514)^{* * *}\end{array}$ & $\begin{array}{l}0.0395 \\
(-1.6460)^{*}\end{array}$ & $\begin{array}{l}-0.0398 \\
(-1.7057)^{*}\end{array}$ \\
\hline Pcexp & 0.0069 & -0.1769 & -0.0003 & -0.0014 \\
\hline
\end{tabular}




\begin{tabular}{|c|c|c|c|c|}
\hline & $(-0.7555)$ & $(0.9755)$ & $(1.8429)^{*}$ & $(-1.3786)^{* * *}$ \\
\hline Fmsiz & $\begin{array}{l}0.0194 \\
(-1.7426)^{*}\end{array}$ & $\begin{array}{l}-0.0053 \\
(-1.2929)^{* *}\end{array}$ & $\begin{array}{l}0.0181 \\
(-0.5195)^{* *}\end{array}$ & $\begin{array}{l}0.4107 \\
(2.0796)^{* *}\end{array}$ \\
\hline Child015 & $\begin{array}{l}-0.0287 \\
(-1.4062)^{* *}\end{array}$ & $\begin{array}{l}-0.0002 \\
(-1.2820)^{* *}\end{array}$ & $\begin{array}{l}-0.0914 \\
(-1.5507)^{* *}\end{array}$ & $\begin{array}{l}0.0187 \\
(1.3168)^{* *}\end{array}$ \\
\hline Child04 & $\begin{array}{l}0.1550 \\
(1.2753)\end{array}$ & $\begin{array}{l}0.0174 \\
(1.2801)^{*}\end{array}$ & $\begin{array}{l}0.2039 \\
(1.5504)^{* * *}\end{array}$ & $\begin{array}{l}-0.3060 \\
(-3.1312)^{*}\end{array}$ \\
\hline Child515 & $\begin{array}{l}0.2258 \\
(1.6576)^{*}\end{array}$ & $\begin{array}{l}0.0006 \\
(2.0551)^{*}\end{array}$ & $\begin{array}{l}0.1323 \\
(1.2877)^{* * *}\end{array}$ & $\begin{array}{l}-0.2026 \\
(-2.9017)^{*}\end{array}$ \\
\hline $\begin{array}{l}\text { No. of } \\
\text { observations }\end{array}$ & 564 & 106 & 510 & 684 \\
\hline $\begin{array}{l}\text { Log of } \\
\text { Likelihood } \\
\text { Function }\end{array}$ & -376.9 & -76.86 & -160.1 & -297.1 \\
\hline $\begin{array}{l}\text { R-Squared } \\
\text { Percent }\end{array}$ & 0.6333 & 0.6057 & 0.6090 & 0.5282 \\
\hline $\begin{array}{l}\text { Correct } \\
\text { Predictions }\end{array}$ & 0.8704 & 0.8419 & 0.8825 & 0.8987 \\
\hline
\end{tabular}

First Stage Results: The first stage results show the probability of going to school and not to work.

In economic literature there is no consensus about whether birth order effect in education of children really exist, and if it exists, whether positive, negative or non-linear in form (Parish and Willis 1993). There are two possible cases (Behrman and Taubman 1986). The first probability is a negative birth order effect. As more children are born, the household resources constraint becomes severe and fewer resources are available per child. If per child resource shrinkage effect is dominant, the younger (high order) siblings will receive less education than other siblings. Alternatively, the resource competition effects might decline overtime, since the household can accumulate assets and increase income overtime. Moreover, the older children may enter the labour market, contributing to household resources. Therefore young children (high order) siblings could spend more years at school. This is the case of positive birth order effect. Moreover, an economy of scale due to household-level public goods might be important as well, since young children can learn easily from the experience of their older siblings through home teaching. In sum, having older siblings might promote the education of a younger child, rather than impede the education of that child, if the resource extension effect, scale economies, and externalities are larger than the competition effect. Our research suggests that birth order exists and more importantly it is negative for the school only decision. The birth-order in his/her brothers and sisters shows that the 
younger brothers and sisters have lower probability of going to school. This may be due to the resource constraint but another explanation more probable may be the delayed enrolment of children in schools.

The male children are more likely to go to school as compared to female children and statistically it is significant. This provides conformation of results by Durrant (1998), Sawada and Lokshin (2000) and Ray (2001). There are several possible explanations for the distinct gender gap. The lack of female schools in rural areas possibly explains this result. Moreover, strict Islamic laws that keep women at home and in comparatively conservative rural communities explains the lower school probability for girls. Sawada and Lokshin (2000) have described that high opportunity cost of daughter's education in Pakistan may lead to apparent intra-household discrimination against women in terms of education. Because of the custom of seclusion of women, parents might have a strong negative perception of female education. The low probability for girls schooling may also reflect the low female teacher availability and quality in schools. The socio-cultural forces also create the needs for women teachers to teach females. The traditional Pakistani culture requires single sex schools. The lack of school availability affects female education more seriously than male education (Shah 1986).

The probability derivative of age is positive and age square is negative so the result of the sequential probit model shows that age is an important variable on the decision about child schooling. More specifically, it implies that the probability of going to school decreases at a decreasing rate. The result is contradictory to the general perception that school participation decreases by increase in age (See, Burki and Fasih 1998). We have taken the minimum age of a child to be in school as 5 years. At this age the children are not sent to school, that is the explanation for the probability derivative being positive. The results again explain the fact that the school enrolment of children is delayed. In Pakistani rural areas the school enrolment is delayed as well (see, Ali and Khan 2003) so regardless of the rural or urban areas the school enrolment of children is delayed at the national level.

We have found that children from the male head of household are slightly more likely to go to school. But Maitra and Ray (2000) found for Pakistan that the gender of the head of the households does not matter in the schooling decision of children. Ali and Khan (2000) found that in rural areas of Pakistan children from a male head of household are less likely to go to school. This makes the impact of the gender of the head of household on the schooling decision ambiguous in economic literature. But the present study revealed the impact of male head of household positive on child 
schooling. The female adults in Pakistan participate in economic activity less due to various socio-cultural reasons, which keeps the income of the females low, so the probability of children from female-headed households remains low. Consequently this involves an economic effect behind the gender effect.

The stage in life cycle of the head of the household has a positive effect in the case of schooling. The older the head of the household, the more likely it is that the child attends school only. The possible explanation may be that the older head of household has comparatively more elder siblings (more than 15 years of age) as compared to a younger head of household. These elder siblings have earning capacity so the financial status of the household is enhanced, resultantly school-going age children are more likely to go to school. Furthermore, if the head of household is older, and is more frequently father or mother of the children, and the elder siblings (more than 15 years of age) are studying instead of earning, the children in the school-going age are more likely to go to school due to economies of scale of education within the household.

The head of the households are critical in determining the child's schooling and labour decision. It is generally perceived that the head of the household's education plays a positive role in child's decision to go to school. For instance Ali and Khan (2003) found that in rural areas of Pakistan the probability of a child going to school increases by 9.7 percent by increase of one year of schooling of head of household on the average. This indicates important complementarity between the education of the head of the household and the child's schooling. This complemetarity is generated possibly by educated parent's positive incentives for educating children, improved technical or allocative efficiency, and/or superior home teaching environments as pointed out by Behrman et. al. (2000). The effect of head of household education underlines the transgenerational links between lack of schooling and child labour. But surprisingly we have concluded a negative relation between the education of the head of the household and probability of going to school.

Ali and Khan (2003) found that in rural areas of Pakistan the employment status of head of household affects schooling positively. The children from an employed head of household are more likely to go to school and not to work. The result highlights the fact that an unemployed head of household cannot ensure himself against income fluctuations that create supply of child labour from the household. But the present study has shown the inverse, i.e. the children from employed head of households are less likely to go to school. But the income level of head of household affects the schooling decision positively. It is concluded that it is not the 
employment status of the head of household but the income level of head of household which affects the schooling decision positively.

The father's education has a significant positive effect on child's schooling. One additional year of education of the father will increase the school participation of children by 21 percent. Mother's education has a positive effect and one additional year of education of the mother will increase school participation by 23 percent. Mother's employment results in 16 percent more probability of the child going to school. Mother's income has a slight but significant positive effect on child's schooling, as the probability derivative for a child to go to school is positive for mother's education. It is evident from the results of parent's parameters about the decisions of child's schooling that mother's characteristics i.e. education, employment and income of the mother are more important when compared to those of the father.

If the household has assets, the child has 8 percent more probability of going to school only. The ownership of assets such as household enterprises, house, land, shop etc. is an obvious measure of a household's wealth. Hence our results suggest that the probability of child's schooling is systematically higher for households with wealth. Moreover, ownership of assets makes the household stable against the fluctuations in income through credit procurement or sale of the assets.

Generally, the household composition does not exert a significant impact on the child's schooling decision and where it does, it is through the number of adults rather than the number of children in the household. In the case of Pakistan we found that the household composition exerts an impact on child's schooling. The impact is through the number of children. The number of children (up to the age of 15 years) in the household has a negative effect. The explanation as given by Ray (2001:10) is that a child living in a household with a large number of children is more likely to be living in poverty than a child residing in a household with few children. Sawada and Lokshin $(2000: 15)$ had the similar results that students who could obtain higher education are from households with a small number of children. This is a reflection of the intra-household resource competition.

Second Stage Results: The second estimation stage eliminates from the sample the children who go to school only. The probability to be determined for the remaining sample is that of combining school and work.

As the birth-order plays an important role in the decision making of child schooling and child labour, it is found that younger children are less 
likely to combine schooling with work. The child's age matters in the decision combining schooling and work, the probability of the child combining schooling and work increases with age. The negative age square suggests, however, that the effect weakens in the higher age group. The results contradict those of Maitra and Ray (2000) for Pakistani rural as well as urban areas. They found that age increases the likelihood that a child goes to school only or work only.

The current years of education of a child increases the probability of combining school and work. It shows that a child has to work to support educational expenditures. As the education level increases the educational cost increases, so the probability of combining schooling and work increases. The same results are found for rural areas by Ali and Khan (2003).

Mother's education is negatively related to the decision of combining school and work. Similarly it is negatively related to the work only and positively related to the school only decision. So it is concluded that there is a strong effect of mother's education on child's schooling and labour decision. It supports the general perception that parental education is associated with lower incidence of child labour and high school attendance rate. Mother's income has a positive relation with the probability of the child combining school and work and negative relation to no-school, nowork decision. As mother's income correlated with mother's education, i.e. educated mothers have more earning opportunity so ultimately the income effect on education represents the mother's education effect. The more educated women or the more earning women perceive their children's education positively and decide for their children to go to school only, as a second option to go to school and work simultaneously, but not to remain in the state of no-school, no-work. It may also be concluded that educated working women perceive education positively on the basis of financial returns to education, as they themselves have gained these returns.

Assets of the household have a negative impact on the child's decision to combine school and work. The more the assets a household has, the less is the probability of the children of that household combining school and work, but more probability of going to school only. The presence of assets in a household, as assets stand as a proxy of wealth, increases the financial status of the household and decreases the fluctuation in the income of the household, so asset owner households do not need to decide to combine schooling with work. That is in these households the education cost is easily affordable by the households. 
The children from large size households are less likely to combine work with schooling. The presence of siblings in the age group of 5-15 years in the household increases the probability of combining school and work. Similarly, presence of infants i.e. siblings less than five years of age increases the probability of the children combining school and work. Here resource competition occurs.

Third Stage Results: The third stage of the estimation looks only at the children who are not in school and determines the probability that they will work for wages or in household enterprises rather than work only at home care tasks or not work at all.

The birth order of the child is negatively related to work only, i.e. elder the child among the brothers and sisters, he/she is more likely to work only. The child participation in wage or household enterprises increases with child age (see also Durrant 1998; Ray 2001). Such a relation shows the dropout of children from school at higher grades. There may be a number of reasons for the phenomenon, that are: as the age of the child increases resultantly the opportunity cost of child increases; by increase in age the school grade increases so education cost also increases; for higher grades there are less number of schools as compared to lower grade schools; the girl's drop-out rate is higher than boys at higher grades due to social discrimination, etc.

The gender of the child also matters and another surprising result is that the boys are less likely to engage in work only than girls. Education level surely has a negative impact on the work only option. The current educational level of the child significantly reduces his/her labour, ceteris paribus an increase in child labour has a significant adverse impact on schooling so a trade off between child labour and schooling is established.

Life cycle of the head of the household has a positive effect at this stage. The more the age of the head of the household, the more likely for the child to work only. Education of the head of household has significant and negative impact on child's work. On average one additional year of education of head of household decreases the probability of child working by 98 percent. The explanation is that the educated head of household perceives the disadvantages of work and benefits of education. Similarly employment level and income of the head of household both have a negative impact on child's work. As the head of the household is a major contributor to household income so employment of the head of the household makes the household income stable and reduces the need for child labour. At the same time the increase in income of the head of the 
household decreases the probability of the child working (see also, Ali and Khan 2003), that is decline in poverty reduces child labour.

The ownership of assets has a negative impact on the decision of the parents to send their children to work only. But for rural areas Ali and Khan (2003) have found a positive impact of ownership of assets, showing a complemetarity between assets and child labour.

Fourth Stage Results: The no-school, no-work or homecare activity decision is positively related to the birth order of the child. The higher the birth order of a child, that is younger the child among brothers and sisters the more likely he/she to be in the state of no school no work. This explains the fact of delayed primary school enrolment as the younger children remain at home. Similarly, no-school no-work or homecare is negatively related to the age of the children. The older is the child he/she is less likely to do homecare or remain in no-school, no-work situation. Each additional year of age of child decreases the likelihood of homecare by 8.2 percent. On the other hand increase in age enhances the probability of going to school, combining school and work and work only. The notion again confirms the fact that school enrolment is delayed in urban households in Pakistan.

Boys are less likely to remain in the state of no-school, no-work. On the other hand they are more likely to go to school. This shows a gender disparity about children's decision by parents.

Age of the head of the household has a significant effect on the child's activities. The children from households with older head of households are less likely to engage in home care/neither school nor work activity, but these children are more likely to go to school only or work only.

Head of household's education decreases the likelihood that the child is engaged in homecare. Each additional year of education of head of household decreases the likelihood of home care by 22.9 percent. Mother's income and employment both have a negative impact on no-school no-work activity.

The ownership of assets by the household decreases the probability of the children doing homecare. The children from households with assets either go to school (evident from first stage results) or work for wages or for household enterprises (from third stage results). So when the assets increase the income of households, the household decides to send their children to 
school, but when they feel some problem in education (other than cost of education), for example, the low quality of education, irrelevant education, lack of interest in education by children, no financial return to education etc. they engage their children in work because they have the opportunity owing to ownership of physical capital assets. It is concluded that the deficiencies in the educational system also cause children to work.

The per capita income of the household has negative probability with no-school no-work decision, that is the children from poor households are more likely to live in no-school no-work status. Due to poverty the poor parents can not send their children to school, even cannot engage them in work, which force them to keep their children in no-school no-work situation. Similarly, children from families with a large number of siblings are more likely to do home-care. The reason behind may be poverty, that is related to the large number of children in the household and it makes the parents unable to send the children to school or work.

\section{Policy Recommendations}

Our results lead to many recommendations. It is significant to note that schooling cannot be enhanced instantly and consequently child labour cannot be eradicated immediately as a number of independent variables need time for change.

Reducing poverty will contribute more than other interventions to enhancing school participation and to eliminate child labour. Among the poverty alleviation programmes the provision of credit to poor households without collateral is significant so the household does not need to rely on their children and send them to school instead.

One policy may be the provision of low cost schools. Education subsidies are another way to transfer resources to poor households. Raising household income through transfer payments may increase school participation and decrease child labour. Government assisted programmes such as the District Primary Education Projects and Integrated Children Development Schemes in India (See, Fallon and Tzannatos 1998:15) Foodfor-Education Program in Bangladesh can act as a role model in the promotion of schooling in Pakistan.

Adult literacy programmes are proposed. Moreover, public awareness about education can play an important role. Gender disparity in education should be minimised and quality education, technical education and relevant education should be provided. 
144 The Lahore Journal of Economics, Vol.9, No.1

Employment of the mother and consequently income are critical determinants of child schooling and child labour, so increase in employment opportunities for females may increase child schooling and decrease child labour. For the employment of women, micro credit through NGOs is important.

The fertility issue is immense so effective population planning programmes are recommended to curtail population pressure and decrease resource competition within the household. 


\section{References}

ADB, 2002, "Poverty in Pakistan: Issues, Causes and Institutional Responses" Asian Development Bank (ADB). Pakistan Resident Mission, Islamabad.

Addison, Tony, Sonia Bhalotra., Fiona Coulter., Christopher Heady, 1997, "Child Labour in Pakistan and Ghana: A Comparative Study" Center for Development Studies, University of Bath, England. (Processed).

Ahmed, Manzooruddin, 1991, "Child Labour-A Time to Reflect" UNICEF, Pakistan and Zakat, Usher and Social Welfare Department, Govt. of Balochistan, Pakistan.

Ali, Karamt and Rana Ejaz Ali Khan, 2003, "Child Labour in Rural Areas of Pakistan-Some Socioeconomic Determinants” Pakistan Economic and Social Review (forthcoming).

Basu, Kaushik and Phan Hoang Van, 1998, "Economics of Child Labour" American Economic Review 88(3).

Behrman, Jere R. and P. Taubman, 1986, "Birth Order, Schooling and Earnings" Journal of Labour Economics 4(3).

Behrman, Jere R., P. Sengupta and P. Todd, 2000, "Progressing Through PROGRESA: An Impact Assessment of Mexico's School Subsidy Experiment" International Food Policy Research Institute (IFPRI), Rome. (Processed)

Burki, Abid A. and Tazeen Fasih, 1998, "Household's Non-Leisure Time Allocation for Children and Determination of Child Labour in Punjab, Pakistan” The Pakistan Development Review 7(4).

Cartwright, Kimberly, 1999, "Child Labour in Colombia" in Grootaert, Christiaan and Harry Anthony Patrinos (eds) 1999 The Policy Analysis of Child Labour: A Comparative Study. St. Martin Press, New York.

Cartwright, Kimberly and Harry Anthony Patrinos, 1999, "Child Labour in Urban Bolivia" in Grootaert, Christiaan and Harry Anthony Patrinos (eds) 1999 The Policy Analysis of Child Labour: A Comparative Study. St. Martin's Press, New York.

DeGraff, Deborah S., Richard E. Bilsborrow and Alejandro N. Herrin, 1993, “The Implications of High Fertility for Children's Time Use in the 
Philippines" in Cynthia B. Lloyd (ed) Fertility, Family Size, and Structure: Consequences for Families and Children. Proceedings of the Population Council Seminar, New York 9-10 June, 1992. The Population Council, New York.

Durrant, Valerie L., 1998, "Community Influences on Schooling and Work Activity of Youth in Pakistan" The Pakistan Development Review 37(4).

Fallon, Peter and Z. Tzannatos, 1998, “Child Labour: Issues and Directions for the World Bank" The World Bank, Washington, D.C.

FBS, 1996, “Child Labour Survey 1996," Federal Bureau of Statistics, Govt. of Pakistan, Islamabad.

Grootaert, Christiaan, 1999a, "Child Labour In Coate d Ivoire: Incidence and Determinants" in Christiaan Grootaert and Harry A. Patrinos (eds) 1999 The Policy Analysis of Child Labour: A Comparative Study. St. Martin's Press, New York. Also, Policy Research Working Paper \#1905. The World Bank, Washington, D.C.

Grootaert, Christiaan, 1999, "Modeling the Determinants of Child Labour" in Christiaan Grootaert and Harry A. Patrinos (eds) 1999 The Policy Analysis of Child Labour: A Comparative Study. St. Martin's Press, New York. Also, Policy Research Working Paper \#1905. The World Bank, Washington, D.C.

Hussain, Akmal, 1985, "Child Labour in Lahore" A Survey Sponsored by Syed Engineers, Lahore.

Khan, Omer Asghar and Karamat Ali, 1991, "Child Work and Family Life in Karachi” A Research Report for SEBCON, SEBCON Karachi.

Khan, Shaheen, 1982, "Compelled Child Labour in Punjab-A Case Study" Punjab Economic Research Institute, Lahore.

Levy, Victor, 1985, "Cropping Pattern, Mechanization, Child Labour and Fertility Behavior in Farming Economy: Rural Egypt" Economic Development and Cultural Change 33:777-791.

Mahmood, Moazam., Tariq Javaid and Ajmal Baig, 1994, "Why Children do not Go to School in Rural Pakistan in Some Estimates and a Theoretical Framework” The Pakistan Development Review 33(4). 
Maitra, Pushkar and Ranjan Ray, 2000, "The Joint Estimation of Child Participation in Schooling and Employment: Comparative Evidence from Three Continents" University of Monash, Victoria, and University of Tasmania, Australia. (Processed).

Parish, W.L. and R.J. Willis, 1993, "Daughters, Education and Family Budgets: Taiwan Experience” Journal of Human Resources 28(4).

Ray, Ranjan, 1999, "Poverty, Household Size and Child Welfare in India". School of Economics, University of Tasmania, Hobart, Australia. (Processed).

Ray, Ranjan, 2000a, "Child Labour, Child Schooling, and Their Interaction With Adult Labour Empirical Evidence for Peru and Pakistan." The World Bank Economic Review (Washington) 14(2): 347-367.

Ray, Ranjan, 2000b, "Analysis of Child Labour in Peru and Pakistan: A Comparative Study” Journal of Population Economics 13.

Ray, Ranjan, 2001, "Simultaneous analysis of Child Labour and Child Schooling: Comparative Evidence from Nepal and Pakistan" Schools of Economics, University of Tasmania, Australia. (Processed).

Rivera-Batiz F.L., 1985, "Child Labour Patterns and Legislation in Relation to Fertility" Department of Economics, Indiana University, Bloomington, Indiana (Processed).

Rosenzweig, Mark R. and Robert Evenson, 1997, "Fertility, Schooling and the Economic Contribution of Children in Rural India: An Economic Analysis" Econometrica 45(5):1065-1079.

Sakellario, Chris and Ashish Lall, 1999, "Child Labour in the Philippines" in Christiaan Grootaert and Harry A. Patrinos (eds) 1999 The Policy Analysis of Child Labour: A Comparative Study. St. Martin's Press, New York. Also, Policy Research Working Paper \#1905. The World Bank, Washington, D.C.

Sawada, Yasuyuki and Michael Lokshin, 2000, "Household Schooling Decisions in Rural Pakistan" Study conducted by Japanese Ministry of Education, The Foundation for Advance Studies on International Development, and Matsushita International Foundation, Japan.

Shah, Nasra M., 1986, "Pakistani Women: A Socioeconomic and Demographic Profile” Pakistan Institute of Development Economics, 
148 The Lahore Journal of Economics, Vol.9, No.1

Islamabad and East-West Population Institute of East-West Center, Honolulu, Hawaii.

Sharif, Mohammad, 1985, "Child Participation, Nature of Work, and Fertility Demand: A Theoretical Analysis” Indian Economic Journal 40(4).

Weiner, Myron and Omar Noman, 1995, The Child and State in India and Pakistan Oxford University Press, Pakistan. 